\title{
Electronic Effects in Oxidation Reactions Utilizing Dinuclear Copper Complexes with the Bis[3-[2- hydroxybenzylideneamino]phenyll Sulfone Ligand
}

\author{
Armando M. Guidote Jr. ${ }^{1,2 *}$, Ronald L. Reyes ${ }^{1}$, Riyo Kashihara ${ }^{2}$, Yasuhiko Kurusu², \\ Yoshiro Masuyama² \\ ${ }^{1}$ Department of Chemistry, School of Science and Engineering, Loyola Schools, Ateneo de Manila University, \\ Loyola Heights, Quezon City 1108 \\ ${ }^{2}$ Department of Materials and Life Sciences, Faculty of Science and Technology, Sophia University, 7-1 Kioicho, \\ Chiyoda-ku, Tokyo 102-8554, Japan
}

\begin{abstract}
Copper acetate and the ligands bis[3-(3-tert-butyl-2-hydroxy-5-methoxybenzylideneamino)phenyl] sulfone and bis[3-(3,5-di-tert-butyl-2-hydroxybenzylideneamino)phenyl] sulfone were reacted to form the complexes with 2:1 copper:ligand ratio, $\mathrm{Cu}_{2}[\mathrm{~B}(t-\mathrm{Bu})$ $(\mathrm{OMe}) \mathrm{BAPS}]\left(\mu-\mathrm{OCH}_{3}\right)_{2}$ (4) and with 2:2 copper:ligand ratio, $\mathrm{Cu}_{2}\left[\mathrm{~B}(t-\mathrm{Bu})_{2} \mathrm{BAPS}\right]_{2}$ (5), respectively. Structures of $\mathbf{4}$ and $\mathbf{5}$ were determined based on IR, UV-Vis, and FAB-MS data in comparison with previously characterized related copper complexes. The two complexes 4 and $\mathbf{5}$ were utilized in the oxidation of the substrates 2,4- and 2,6-di-tertbutylphenol (dtbp) at $-50^{\circ} \mathrm{C}$ with $\mathrm{H}_{2} \mathrm{O}_{2}$ in $\mathrm{CH}_{2} \mathrm{Cl}_{2}$. The coupling products are preferred in both cases. For 2,4-dtbp, yields of $4,600 \%$ and $7,200 \%$ of 3,3',5,5'-tetra-tert-butyl-2,2'biphenol were achieved with the use of 4 and 5, respectively. For 2,6-dtbp, yields of $1,900 \%$ and $400 \%$ of 3,3',5,5'-tetra-tert-butyl-4,4'-biphenol were realized utilizing $\mathbf{4}$ and $\mathbf{5}$, respectively. These show that the methoxy groups activated the complex. Based on low temperature UV-vis results, a $\mu-\eta^{2}: \eta^{2}$-peroxo or a $\mu$-hydroperoxo intermediate was possibly formed by the reaction of 4 with the $\mathrm{H}_{2} \mathrm{O}_{2}$. This effected the oxidation of the 2,4- and 2,6dtbp substrates but also resulted in the attack of other complexes which acted as substrates. A proposed oxidation mechanism using complex $\mathbf{4}$ and related complexes is presented.
\end{abstract}

Keywords: catalysis; copper complex; dinuclear; bydrogen peroxide; oxidation

\section{INTRODUCTION}

Different metal ions play central roles in various coordination complexes in the facilitation or inhibition of chemical reactions essential in life processes. Some of the notable critical processes requiring metal ions include respiration, metabolism, development, signal transduction, and photosynthesis. The biomimetic chemistry of metal containing proteins and enzymes has produced a variety of synthetic systems that contributed to our

*Author to whom correspondence should be addressed; email: aguidote@ateneo.edu 
understanding of how proteins function. More importantly, the role of various metalloenzymes and their synthetic analogs as essential catalysts in oxidation reaction for laboratory and industrial use is indispensable (Weiner et al. 2010, Tolman et al. 2006, Punniyamurthy et al. 2005, Gamez 2004, Sima’ndi 2003, Funabiki 1997).

It is very challenging to study metalloenzymes because of their huge sizes and as such, small molecule models have been found to be useful (Fenton 1995). The reactivity of the metalloenzyme lies mainly in the active site, i.e. the metal centers and the immediate surrounding ligands. Several factors control the coordination of metalloproteins and metalloenzymes. Among these factors include steric and electrostatic repulsion (Panek 2009), electronic structures and metal orbital energies (Kleifeld 2003), and the constraints imposed by proteins (Estiu 2004). Bioinorganic complexes, furthermore, are susceptible in changing acid-base reactivity and oxidationreduction potentials (Panek 2009). Synthetic models of various metalloenzymes have been successful in the deduction of the structure and understanding the mechanisms of chemical reactions mediated by these naturally occurring bioinorganic complexes.

Copper containing enzymes and proteins constitute a general class of important bioinorganic complexes. Proteins containing copper ions at the active site are mainly involved as redox catalysts in a range of biological processes, such as electron transfer, dioxygen transport and oxidation of various bio-substrates (Gamez 2004). One of the most studied enzymes in biomimetic chemistry is galactose oxidase, GOase. Galactose oxidase is a fungal enzyme, produced by Dactylium dendroides, that has found its main use in the quantitative determination of galactose in blood and other biological fluids. First isolated in 1959, this type-2 copper site containing enzyme selectively catalyzes the two-electron oxidation of galactose and primary alcohols to the corresponding aldehydes with the corresponding simultaneous reduction of molecular oxygen to hydrogen peroxide (Tolman 2006, Baron et al. 1994). The first effective bio-inspired catalysts described for galactose oxidase were described in 1998 - a $\mathrm{Cu}(\mathrm{II})$ species, namely [Cu(II)BSP] where BSP symbolises a salen-type ligand with a binaphthyl backbone and thioether functions able to catalyse the oxidation of benzylic and allylic alcohols under dioxygen at room temperature (Stack et al. 1998).

Tyrosinase (E.C.1.14.18.1; monophenol monoxygenase) is another copper-centered protein, widely distributed throughout the phylogenetic scale from bacteria to mammals (Ikehata 2000) that acts as an oxygenase and results in phenol conversion to catechol and eventually to quinone (Fenton 1995, Kitajima \& Moro-oka 1994). These reactions are important because of their tremendous potential in bioremediation (Vinci et al. 2004). Since there is no crystal structure of the active site of tyrosinase, various reactivity and spectroscopic data have been used in the elucidation of its structure and activity (Solomon et al. 2001). Structurally, tyrosinase share the same type 3 copper protein with hemocyanin and their spectroscopic charateristics are similar to that of tyrosinase (Decker and Tukzek 2000). Several models have been made on tyrosinase using different ligand systems (Lewis \& Tolman 2004). Notably, a structural model based on a mononuclear copper precursor which, when exposed to molecular oxygen, forms a binuclear compound: $\left[\{\mathrm{Cu}(\mathrm{II})(\mathrm{MeAN})\}_{2}\left(\mathrm{O}_{2}\right)\right]^{2+}$ $\left(\mathrm{MeAN}=\mathrm{N}, \mathrm{N}, \mathrm{N}, \mathrm{N}^{\prime}, \mathrm{N}{ }^{\prime}\right.$ - pentamethyl dipropylenetriamine) shows good agreement with the natural enzyme using Raman spectroscopy and UV-Vis studies (Liang et al. 2002, Mirica et al. 2002, Itoh et al. 2001).

In the present study, we have utilized a series of bis[3-(2-hydroxybenzylideneamino)phenyl] sulfone as ligand to model tyrosinase (Guidote et al. 2001) and this included the complexes with the unsubstituted (1), tert-butylsubstituted (2) and chlorine-substituted (3) ligands, shown in scheme 1 . To look more into electronic and steric effects, we now report the preparation of a complex with 
methoxy-substituted (4) ligand. This has resulted into an increase in reactivity of the copper complex. Another complex with additional tert-butyl substituents (5) was prepared resulting into a 2:2 Cu:ligand complex. We also present a proposed mechanism of the oxidation process using our small molecule models.

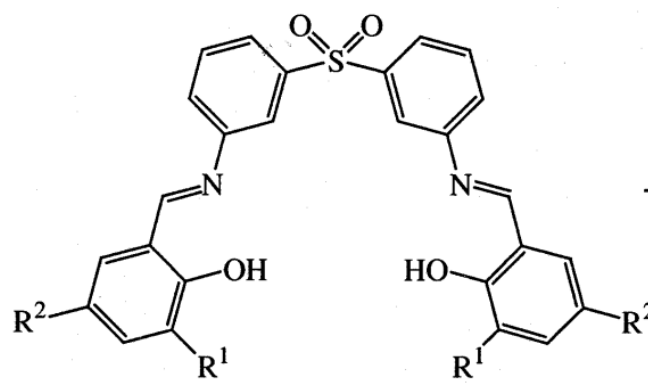

BHBAPS: $\mathrm{R}^{1}=\mathrm{H} ; \mathrm{R}^{2}=\mathrm{H}$

BH( $t$-Bu)BAPS: $\mathrm{R}^{1}=t-\mathrm{Bu} ; \mathrm{R}^{2}=\mathrm{H}$ BHCl $_{2}$ BAPS: $\mathrm{R}^{1}=\mathrm{Cl} ; \mathrm{R}^{2}=\mathrm{Cl}$

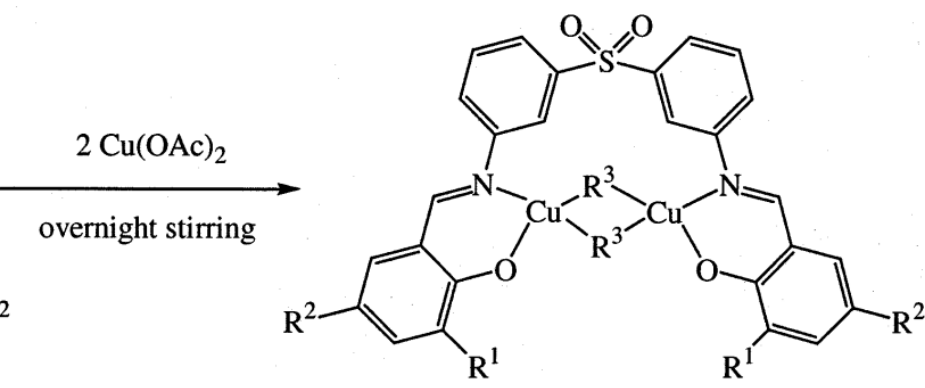

1: $\mathrm{R}^{1}=\mathrm{H} ; \mathrm{R}^{2}=\mathrm{H} ; \mathrm{R}^{3}=\mathrm{OMe}$

2: $\mathrm{R}^{1}=t-\mathrm{Bu} ; \mathrm{R}^{2}=\mathrm{H} ; \mathrm{R}^{3}=\mathrm{OH}$

3: $\mathrm{R}^{1}=\mathrm{Cl} ; \mathrm{R}^{2}=\mathrm{Cl} ; \mathrm{R}^{3}=\mathrm{OMe}$

Scheme 1. The preparation of the unsubstituted (1), tert-butyl-substituted (2) and chlorine-substituted (3) model tyrosinase complexes (Guidote et al. 2001).

\section{MATERIALS AND METHODS}

The triethylamine, THF and diethyl ether used for the salicylaldehyde starting material syntheses were freshly distilled prior to use. All other starting materials and solvents used were purchased commercially and used as received. Proton NMR spectra and infrared (IR) spectra were measured using a $500 \mathrm{MHz}$ JNM-LA500 and a Shimadzu FTIR-8300, respectively. UV-vis spectra were recorded on a Shimadzu MultiSpec-1500 at room temperature with $\mathrm{CH}_{2} \mathrm{Cl}_{2}$ as solvent. For low temperature UV-vis measurements, an Alpha Engineering Ltd. CS-96-2 cryostat and Model TC 22-A thermo controller were utilized. High resolution and electron-ionization mass spectrometric measurements were carried out on a JEOL JMS-SX102A. For the complex, fast atomic bombardment (FAB) with $p$ nitrobenzyl alcohol (NBA) as matrix was utilized. Elemental analyses were obtained with the use of a Perkin-Elmer 2400-II and magnetic susceptibility measurements were done by way of the Faraday method using a CAHN 1000 Electrobalance and $\mathrm{Hg}\left[\mathrm{Co}(\mathrm{SCN})_{4}\right]$ as reference compound.

\section{$\mathrm{Cu}_{2}[\mathrm{~B}(\mathrm{t}-\mathrm{Bu})(\mathrm{OMe}) \mathrm{BAPS}]\left(\mu-\mathrm{OCH}_{3}\right)_{2}$} The solid $\mathbf{B H}(\boldsymbol{t}$-Bu)(OMe)BAPS (0.30 g, $0.50 \mathrm{mmol})$ was added directly to a $\mathrm{Cu}(\mathrm{OAc})_{2} \cdot \mathrm{H}_{2} \mathrm{O} \quad(0.29 \mathrm{~g}, \quad 1.5 \mathrm{mmol}) \quad$ in methanol $(150 \mathrm{~mL})$. Brown crystals of 4 were obtained by diffusion of ether to a $\mathrm{CH}_{2} \mathrm{Cl}_{2}$ solution of the precipitated powder. The yield was $0.20 \mathrm{~g}, 50 \%$.

IR $\left(\mathrm{KBr}, \mathrm{cm}^{-1}\right): 1155,1215,1306,1468,1585$, 1603, 2953. UV-vis $\left(n m\left(\varepsilon / M^{-1} \mathrm{~cm}^{-1}\right)\right): 242$ (41000), 297 (33000), 444 (17000). FAB-MS (m/ v): 754, 904, 1056. Magnetic Moment (BM): 0.99. Anal. Calc. for $\mathrm{C}_{38} \mathrm{H}_{44} \mathrm{~N}_{2} \mathrm{O}_{8} S \mathrm{Cu}$ : C, 55.94; H, 5.44; N, 3.43. Found: C, 51.05; H, 5.00; N, $3.05 \%$.

Preparation of $\mathrm{Cu}_{2}\left[\mathrm{~B}(\mathrm{t}-\mathrm{Bu})_{2} \mathrm{BAPS}\right]_{2}$ (5). The ligand $\mathbf{B H}(\boldsymbol{t}-\mathbf{B u})_{2} \mathbf{B A P S}(0.14 \mathrm{~g}, 0.20$ $\mathrm{mmol})$ was dissolved in THF $(20 \mathrm{~mL})$ and methanol $(20 \mathrm{~mL})$. This solution was added to copper acetate monohydrate $(0.16 \mathrm{~g}$, $0.80 \mathrm{mmol})$ in $\mathrm{MeOH}(30 \mathrm{~mL})$. After overnight stirring, the brown powder of $\mathbf{5}$ was collected. This is recrystallized by diffusion of ether to a dichloromethane solution of $\mathbf{5}$. The yield of the brown crystals was $0.30 \mathrm{~g}, 50 \%$.

IR $\left(\mathrm{KBr}, \mathrm{cm}^{-1}\right): 1155,1304,1479,1583,1605$, 2955. UV-vis $\left(\mathrm{nm}\left(\varepsilon / M^{-1} \mathrm{~cm}^{-1}\right)\right): 238$ (150000), 296 (130000), 427 (47000). FAB-MS (m/ q): 681, 742, 805, 1484. Magnetic Moment (B.M): 1.86. Anal. Calc. for $\mathrm{C}_{86} \mathrm{H}_{104} \mathrm{~N}_{4} \mathrm{O}_{8} \mathrm{Cl}_{2} \mathrm{~S}_{2} \mathrm{Cu}_{2}$ : C, 62.49; H, 6.34; N, 3.39. Found: C, 62.27; H, $6.62,3.16 \%$. 
Oxidation of 2,4- and 2,6-Di-tert-butylphenol (dtbp) Using the Complexes and $\mathrm{H}_{2} \mathrm{O}_{2}$. In DCM or THF $(15 \mathrm{~mL})$ were dissolved the subtrates $2,4-$ or $2,6-\mathrm{dtbp}(0.21 \mathrm{~g}, 1.0 \mathrm{mmol})$ and the complexes 4 and $5(0.010 \mathrm{mmol})$, respectively. This was then cooled for $2 \mathrm{~h}$ at $-50{ }^{\circ} \mathrm{C}$ in a constant temperature bath. After this, 5 drops of $30 \%$ (aq.) $\mathrm{H}_{2} \mathrm{O}_{2}$ were added and the solution was stirred for $24 \mathrm{~h}$. Normal work-up was done with $10 \% \mathrm{HCl}$ and extraction with DCM $(30 \mathrm{~mL})$. This was repeated three more times ( $40 \mathrm{ml}$ each). The combined DCM solution was dried with $\mathrm{MgSO}_{4}$, filtered and the solvent removed by rotary evaporation. The reaction mixture for 2,4-dtbp was separated by column chromatography. For 2,6-dtbp, the product components were isolated by using a JAI LC908 preparative HPLC after a prior column chromatography to remove the reactant (Guidote et al. 2001).

Low Temperature UV-Vis Studies. UVVis spectra were recorded on a Shimadzu Multi-Spec-1500 with an Alpha Engineering Ltd. CS-96-2 cryostat and Model TC22-A thermo controller. A solution of the complex in THF was prepared. The solution was cooled at $-50{ }^{\circ} \mathrm{C}$ for two hours followed by the addition of $30 \% \mathrm{H}_{2} \mathrm{O}_{2}$. The spectra were obtained at certain time intervals.

\section{RESULTS AND DISCUSSION}

Ligand and Complex Syntheses. The ligand bis[3-(3-tert-butyl-2-hydroxy-5-methoxybenzyl ideneamino)-phenyl] sulfone, $\mathbf{B H}(\boldsymbol{t}-\mathbf{B u})$ (OMe)BAPS, was prepared from 3-tert-butyl2-hydroxy-5-methoxybenzaldehyde (Wang et al. 1994). Complex 4 is formed by mixing 1 equivalent of the solid $\mathbf{B H}(\boldsymbol{t}-\mathbf{B u})(\mathbf{O M e})$ BAPS ligand with a little more than 2 equivalents of the copper acetate monohydrate, Figure 1. Details regarding the synthesis are provided in the Supporting Information.

The syntheses of 3,5-di-tert-butyl-2hydroxybenzaldehyde and bis[3-(3,5-di-tertbutyl-2-hydroxybenzylideneamino)phenyl]

sulfone, $\mathbf{B H}(\boldsymbol{t}-\mathbf{B u})_{2} \mathbf{B A P S}$, are analogous to the preparations of 3-tert-butyl-2-hydroxy-5methoxybenzaldehyde and $\mathbf{B H}(\boldsymbol{t}-\mathbf{B u})(\mathbf{O M e})$ BAPS, respectively. (See Supporting Information).

Shown in Figure 2 is the synthesis of $\mathbf{5}$. The ligand $\mathbf{B H}(\boldsymbol{t}-\mathbf{B u})_{2} \mathbf{B A P S}(1$ equivalent) is dissolved in a 1:1 THF:methanol solvent system and added to excess copper acetate monohydrate (4 equivalents) in $\mathrm{MeOH}$ in a similar manner as in the preparation of $\mathbf{1}$ (Guidote et al. 2001). The product, however, is a 2:2 copper:ligand complex.

Characterization. Complexes $\mathbf{4}$ and $\mathbf{5}$ were analyzed by FT-IR spectroscopy, UV-Vis spectroscopy and FAB-MS. Selected peaks and their assignments are shown in the supporting information. Based on the analogous preparation and the similarities of the FT-IR, UV-Vis and FAB-MS spectra, we propose that the structure of complex 4 (Figure 1) is similar to that of complexes 1-3. Complex 1 has been crystallographically characterized (Guidote et al. 2001). The structure of complex $\mathbf{5}$ is strongly supported by the molar absorptivity values from the UV-vis results and the 1484 $\mathrm{m} / \mathrm{z}$ signal from the FAB-MS spectrum. The

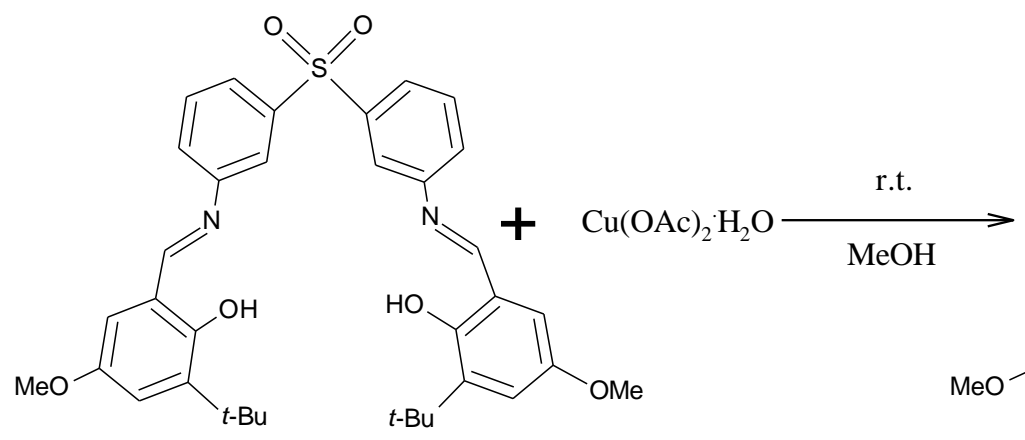

B(t-Bu)(OMe)BAPS

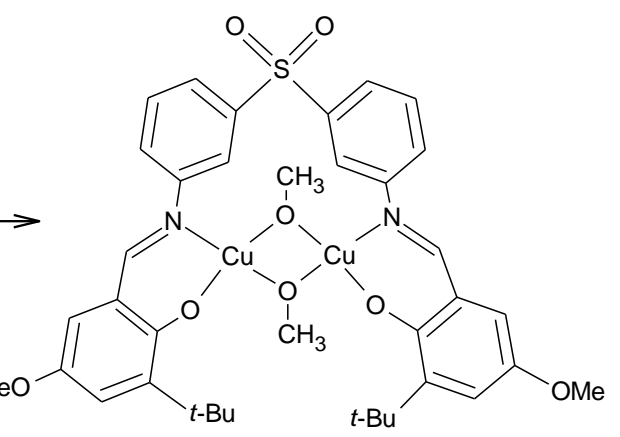

4

Figure 1. Synthesis of complex 4. 

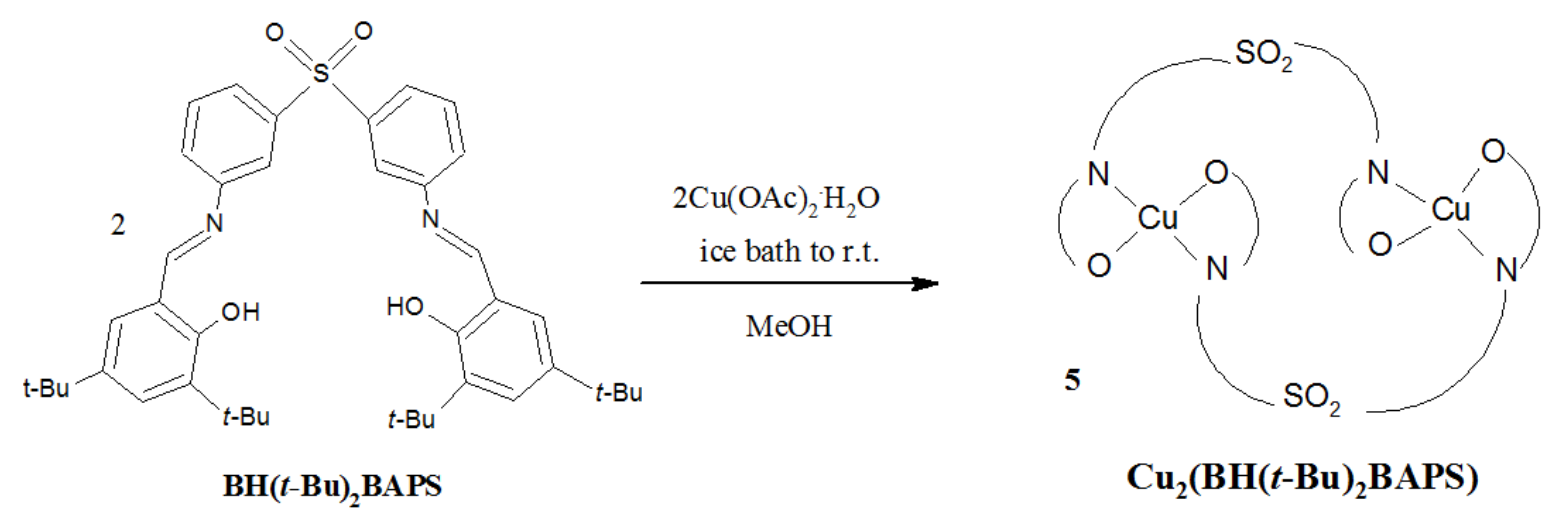

Figure 2. Synthesis of complex $\mathbf{5}$.

large magnetic moment of $\mathbf{5}$ (1.86 B.M) indicates that the two copper atoms are relatively far from each other unlike in 1-3 (Guidote et al. 2001). The following signals were obtained 1H NMR (CDCl3): $\delta 1.46(\mathrm{~s}$, $18 \mathrm{H}, \mathrm{t}-\mathrm{Bu}), 6.90(\mathrm{t}, J=7.63,2 \mathrm{H}, \mathrm{Ar}), 7.29(\mathrm{dd}$, $J=1.53,7.63,2 \mathrm{H}, \mathrm{Ar}), 7.43(\mathrm{dd}, J=1.53,7.63$, $2 \mathrm{H}, \mathrm{Ar}), 7.49$ (m, 2H, Ar), $7.58(\mathrm{t}, J=8.24,2 \mathrm{H}$, Ar), 7.86-7.88 (m, 4H, Ar), $8.66(\mathrm{~s}, 2 \mathrm{H}, \mathrm{C}=\mathrm{N})$. Shifts were observed when compared to the ligands due to the metal-ligand interaction.

Oxidation Reactions. Complexes $\mathbf{4}$ and $\mathbf{5}$ were utilized in the oxidation of 2,4- and 2,6-di-tertbutylphenol (Figures 3 and 4). The results are compared with the related complexes 1-3 along with copper (II) acetate monohydrate (Guidote et al. 2001) in Tables 1 and 2.

Looking at the results from Tables 1 and 2, in general, it can be said that in $\mathrm{CH}_{2} \mathrm{Cl}_{2}$ there is a preference for the coupling products, both diphenoquinone and biphenol (Entries 1, 3 and 7 of both Tables). In THF, there is an increase in the production of quinone (Entries 1-2, 3-4 and 7-8 of both Tables). The very low yield for 3 in $\mathrm{CH}_{2} \mathrm{Cl}_{2}$ is caused by its insolubility at low temperature (Entries 5-6 for both Tables). This is the same case with $\mathbf{5}$ in THF. Complex 3 dissolves in THF, but still, the yields are low. This may be the effect of the electron-withdrawing $\mathrm{Cl}$ atoms towards the reactivity of these copper complexes (Guidote et al. 2001). It was hoped that 4 with electron-donating methoxy groups (Entries 78 for both Tables) would result into higher yields but the results show otherwise. Complex 5 showed the best yield of 7,200\% (Entry 10, Table 1) for 2,4-dtbp oxidation based on the amount of complex. With 2,6dtbp as substrate, the yield using $\mathbf{5}$, compared with the yield using 1-2 are contrasting and may indicate a different reaction mechanism for $\mathbf{5}$ specially since the structure of $\mathbf{5}$ is different from 1 .

Looking at the results from Tables 1 and 2, in general, it can be said that in $\mathrm{CH}_{2} \mathrm{Cl}_{2}$ there is a preference for the coupling products, both diphenoquinone and biphenol (Entries 1, 3 and 7 of both Tables). In THF, there is an increase in the production of quinone (Entries 1-2, 3-4 and 7-8 of both Tables). The very low yield for 3 in $\mathrm{CH}_{2} \mathrm{Cl}_{2}$ is caused by its insolubility at low temperature (Entries 5-6 for both Tables). This is the same case with $\mathbf{5}$ in THF. Complex 3 dissolves in THF, but still, the yields are low. This may be the effect of the electron-withdrawing $\mathrm{Cl}$ atoms towards the reactivity of these copper complexes (Guidote et al. 2001). It was hoped that 4 with electron-donating methoxy groups (Entries 78 for both Tables) would result into higher yields but the results show otherwise. Complex $\mathbf{5}$ showed the best yield of 7,200\% (Entry 10, Table 1) for 2,4-dtbp oxidation based on the amount of complex. With 2,6dtbp as substrate, the yield using $\mathbf{5}$, compared with the yield using 1-2 are contrasting and may indicate a different reaction mechanism for $\mathbf{5}$ specially since the structure of $\mathbf{5}$ is different from 1. 

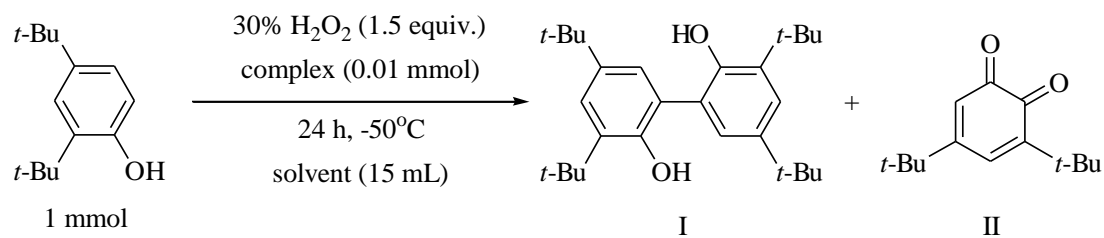

Figure 3. Oxidation of 2,4-di-tert-butylphenol using 1-5.

Table 1. Results of 2,4-di-tert-butylphenol oxidation using 1-5.

\begin{tabular}{ccccc}
\hline Entry & Complex & Solvent & I, Yield $/ \%$ & II, Yield $/ \%$ \\
\hline $1^{\text {a }}$ & $\mathbf{1}$ & $\mathrm{CH}_{2} \mathrm{Cl}_{2}$ & 4,700 & Trace \\
\hline $2^{\mathrm{a}}$ & $\mathbf{1}$ & $\mathrm{THF}$ & 2,600 & 1,600 \\
\hline $3^{\mathrm{a}}$ & $\mathbf{2}$ & $\mathrm{CH}_{2} \mathrm{Cl}_{2}$ & 6,300 & 1,000 \\
\hline $4^{\mathrm{a}}$ & $\mathbf{2}$ & $\mathrm{THF}$ & 3,100 & 1,300 \\
\hline $5^{\mathrm{a}}$ & $\mathbf{3}$ & $\mathrm{CH}_{2} \mathrm{Cl}_{2}$ & 200 & 0 \\
\hline $6^{\mathrm{a}}$ & $\mathbf{3}$ & $\mathrm{THF}$ & 1,600 & 0 \\
\hline 7 & $\mathbf{4}$ & $\mathrm{CH}_{2} \mathrm{Cl}_{2}$ & 2,700 & Trace \\
\hline 8 & $\mathbf{4}$ & $\mathrm{THF}$ & 3,400 & 1,000 \\
\hline $9^{\mathrm{b}}$ & $\mathbf{4}$ & $\mathrm{CH}_{2} \mathrm{Cl}_{2}$ & 4,600 & Trace \\
\hline 10 & $\mathbf{5}$ & $\mathrm{CH}_{2} \mathrm{Cl}_{2}$ & 7,200 & Trace \\
\hline 11 & $\mathbf{5}$ & $\mathrm{THF}$ & Trace & 0 \\
\hline 12 & $\mathrm{Cu}(\mathrm{OAc})_{2}{ }^{\mathrm{c}}$ & $\mathrm{CH}_{2} \mathrm{Cl}_{2}$ & Trace & 0 \\
\hline 13 & $\mathrm{Cu}(\mathrm{OAc})_{2}{ }^{\mathrm{c}}$ & $\mathrm{THF}$ & N.R. & N.R. \\
\hline
\end{tabular}

aGuidote et al 2001; ${ }^{b} 0.005$ mmol; 'monohydrate. Reported yield is based on the complex.

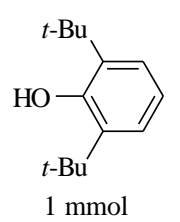

$30 \% \mathrm{H}_{2} \mathrm{O}_{2}$ (1.5 equiv.)

complex $(0.01 \mathrm{mmol})$

$24 \mathrm{~h},-50^{\circ} \mathrm{C}$

solvent $(15 \mathrm{~mL})$

$1 \mathrm{mmol}$<smiles>CC(C)CC1=CC(=C2C=C(CC(C)C)C(=O)C(CC(C)C)=C2)C=C(CC(C)C)C1=O</smiles>

III<smiles>CC(C)CC1=CC(=O)C=C(CBr)C1=O</smiles>

IV<smiles>CCC(C)c1cc(-c2cc(CC(C)C)c(O)c(CC(C)C)c2)cc(CC(C)C)c1O</smiles>

V

Figure 4. Oxidation of 2,6-di-tert-butylphenol using 1-5.

Table 2. Results of of 2,6-di-tert-butylphenol oxidation using 1-5.

\begin{tabular}{cccccc}
\hline Entry & Complex & Solvent & III, Yield $/ \boldsymbol{\%}$ & IV, Yield $/ \boldsymbol{\%}$ & V, Yield $/ \boldsymbol{\%}$ \\
\hline $1^{\mathrm{a}}$ & $\mathbf{1}$ & $\mathrm{CH}_{2} \mathrm{Cl}_{2}$ & 4,300 & 300 & 0 \\
\hline $2^{\mathrm{a}}$ & $\mathbf{1}$ & $\mathrm{THF}$ & 4,200 & 2,500 & 0 \\
\hline $3^{\mathrm{a}}$ & $\mathbf{2}$ & $\mathrm{CH}_{2} \mathrm{Cl}_{2}$ & 3,900 & 800 & 0 \\
\hline $4^{\mathrm{a}}$ & $\mathbf{2}$ & $\mathrm{THF}$ & 1,200 & 4,000 & 0 \\
\hline $5^{\mathrm{a}}$ & $\mathbf{3}^{\mathrm{b}}$ & $\mathrm{CH}_{2} \mathrm{Cl}_{2}$ & 0 & 0 & Trace \\
\hline $6^{\mathrm{a}}$ & $\mathbf{3}^{\mathrm{b}}$ & $\mathrm{THF}$ & 0 & 0 & 400 \\
\hline 7 & $\mathbf{4}$ & $\mathrm{CH}_{2} \mathrm{Cl}_{2}$ & 400 & 400 & 1,900 \\
\hline 8 & $\mathbf{4}$ & $\mathrm{THF}$ & 100 & 1,300 & 300 \\
\hline 9 & $\mathbf{5}$ & $\mathrm{CH}_{2} \mathrm{Cl}$ & Trace & 100 & 400 \\
\hline 10 & $\mathbf{5}$ & $\mathrm{THF}$ & Trace & Trace & Trace \\
\hline 11 & $\mathrm{Cu}(\mathrm{OAc})_{2}{ }^{\mathrm{c}}$ & $\mathrm{CH}_{2} \mathrm{Cl}$ & Trace & Trace & Trace \\
\hline 12 & $\mathrm{Cu}(\mathrm{OAc})_{2}$ & $\mathrm{THF}$ & Trace & Trace & Trace \\
\hline
\end{tabular}

${ }^{a}$ Guidote et al 2001; ${ }^{b} 0.005$ mmol; ${ }^{c}$ monohydrate. . Reported yield is based on the complex. 
Low Temperature $U V$-vis Studies. The results for the low temperature UV-vis measurements for the reaction of the complex 4 with $\mathrm{H}_{2} \mathrm{O}_{2}$ are shown in Figures 5 and 6 , divided into Stages 1 and 2, respectively. The low temperature UV-Vis studies for complexes 1, 2, and 3 were compared as reported (Guidote et al. 2001). The reaction was divided into two stages to monitor possible formation of intermediates as indicated by the changes in the absorptivity of the complex and that of the corresponding spectra.

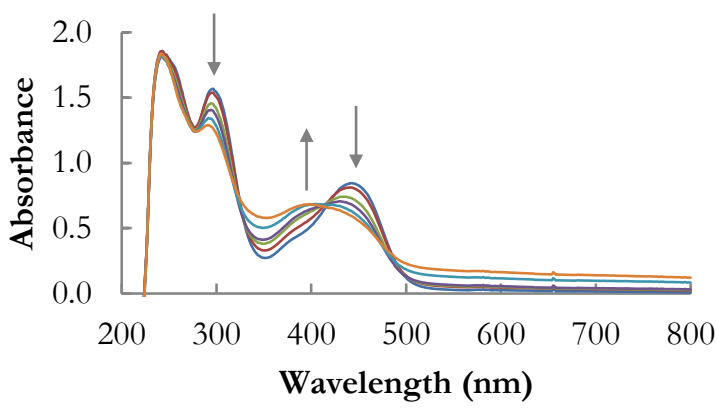

Figure 5. UV-Vis spectra for the reaction of $\mathbf{4}$ and $\mathrm{H}_{2} \mathrm{O}_{2}$ in $\mathrm{CH}_{2} \mathrm{Cl}_{2}$ at $-50^{\circ} \mathrm{C}$ (Stage 1). An upward arrow indicates increasing absorbance and a downward arrow indicates decreasing absorbance at that particular wavelength.

After the addition of $\mathrm{H}_{2} \mathrm{O}_{2}$, the peaks at 297 and $444 \mathrm{~nm}$ start to decay (Figure 5). This is accompanied by the growth of the peak at 398 $\mathrm{nm}$ (Stage 1). This $398 \mathrm{~nm}$ peak reaches a maximum after approximately $0.7 \mathrm{~h}$ and afterwards starts to decay (Figure 6, Stage 2). The final spectrum (after $\sim 2 \mathrm{~h}$ since $\mathrm{H}_{2} \mathrm{O}_{2}$ was added) is very much different from the starting spectrum indicating the decomposition of 4 .

The growth of the peaks in Figure 5 for 4 indicates the possibility of the formation of a $\mu-\eta^{2}: \eta^{2}$-peroxo intermediate based on a comparison with other intermediates (Stack et al. 2004) and the $\mu-\eta^{2}: \eta^{2}$-peroxo intermediate (6) coming from 1 (Guidote et al. 2001), Figure 7. These have: $1_{\max }=338-365 \mathrm{~nm}$, e $=$ 11-38 $\mathrm{mM}^{-1} \mathrm{~cm}^{-1}$ and $l_{\max }=425-532 \mathrm{~nm}, \mathrm{e}=$ $0.8-5 \mathrm{mM}^{-1} \mathrm{~cm}^{-1}$. The formed intermediate, 7 , shown in Figure 7 has similar UV-vis spectral properties to oxyhemocyanin and oxytyrosinase (Table 3).

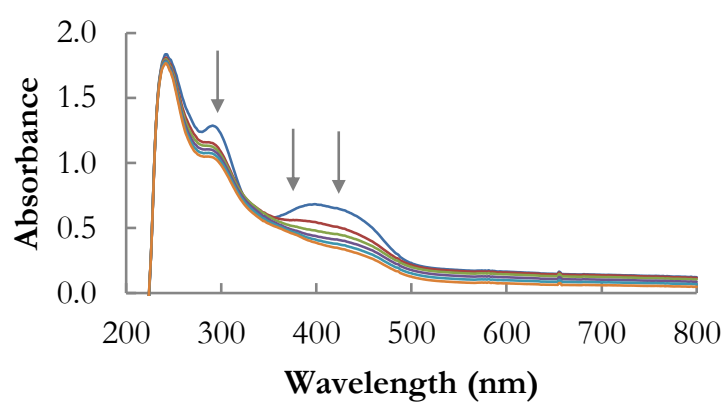

Figure 6. UV-V is spectra for the reaction of 4 and $\mathrm{H}_{2} \mathrm{O}_{2}$ in $\mathrm{CH}_{2} \mathrm{Cl}_{2}$ at $-50^{\circ} \mathrm{C}$ (Stage 2). A downward arrow indicates decreasing absorbance at that particular wavelength.

The peaks are also close to those of the hydroperoxodicopper(II) complex that utilized the ligand XYL-H or a,a'-bis[N,Nbis[2-(2-pyridyl)ethyl]amino]-m-xylene, 395 $\mathrm{nm}\left(\mathrm{e}=8000 \mathrm{M}^{-1} \mathrm{~cm}^{-1}\right)$ and $620 \mathrm{~nm}(\mathrm{e}=450$ $\left.\mathrm{M}^{-1} \mathrm{~cm}^{-1}\right)$, thus, this intermediate cannot be discounted (Karlin et al. 1987, Karlin et al. 1988). However, these peaks are also similar to those of another known intermediate, bis moxo (Stack et al. 2004). The UV spectral range for this is $1_{\max }=297-435 \mathrm{~nm}, \mathrm{e}=9-23 \mathrm{mM}^{-}$ ${ }^{1} \mathrm{~cm}^{-1}$ and $1_{\max }=393-494 \mathrm{~nm}, \mathrm{e}=0.3-28 \mathrm{mM}^{-}$ ${ }^{1} \mathrm{~cm}^{-1}$. This is probable because of interconversion between $\mu-\eta^{2}: \eta^{2}$-peroxo and bis m-oxo peroxo intermediates (Cahoy et al. 1999, Tolman et al. 2004, Stack et al. 2006).

It was expected that 4 with electron-donating methoxy groups would be more reactive than 1 and 2 since the use of 3 with electronwithdrawing $\mathrm{Cl}$ atoms resulted to very low yields in THF. The intermediate 7 may preferentially attack the salicyl moiety of 4 or 7 instead of the phenol despite its great amount and cause decomposition of the complex. The methoxy groups of the salicyl moiety activate each of the two aromatic rings and make it more susceptible to attack by 7 over the phenol substrate. After reaction, 7 can go back to the catalytically inactive form, react with $\mathrm{H}_{2} \mathrm{O}_{2}$ to form the peroxo complex, and subsequently, once again, react with the substrate or complex 4 which is now dwindling in amount. This causes the low yield using 4 relative to 1 and 2 . 

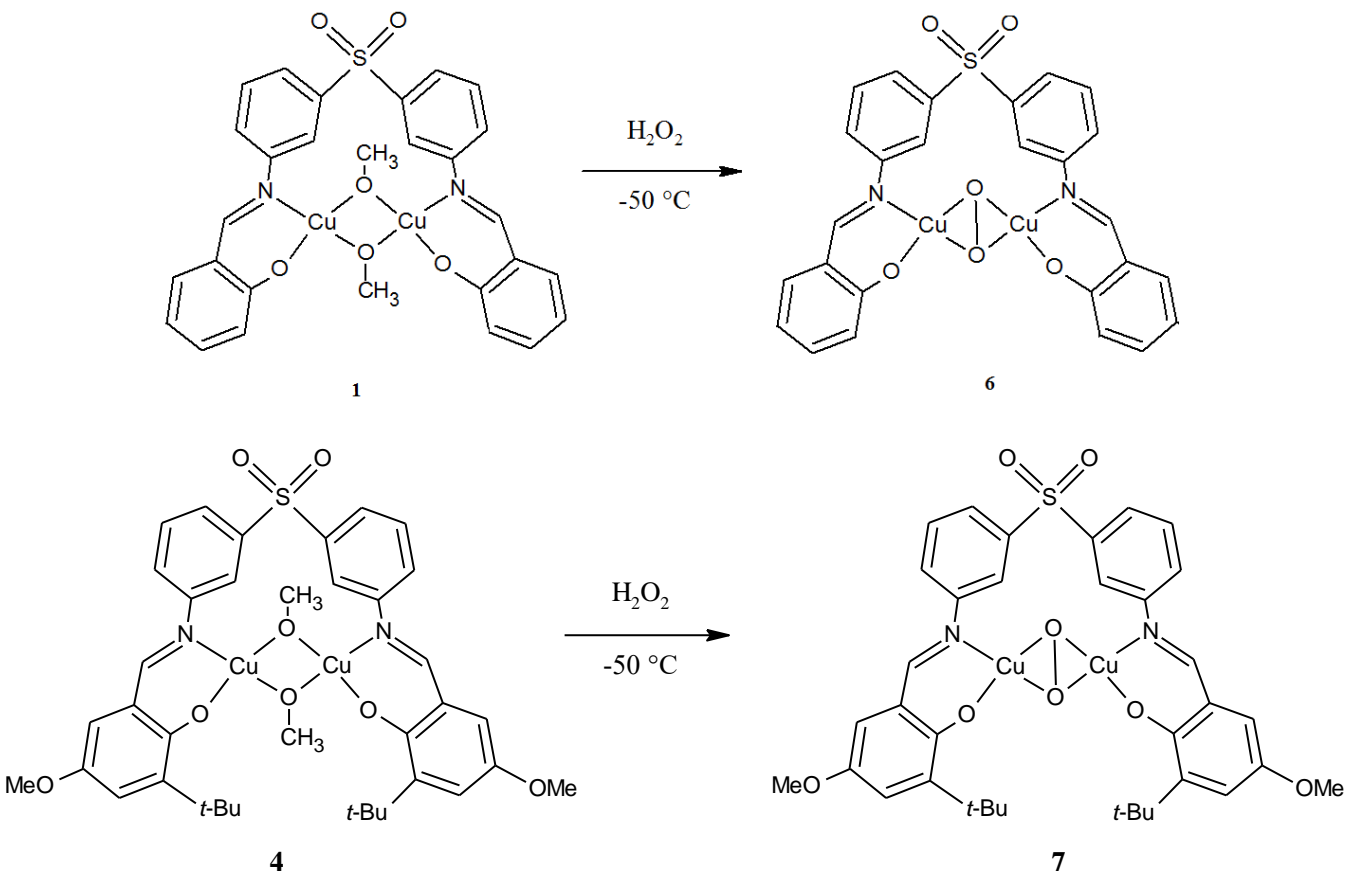

Figure 7. Possible formation of $\mu-\eta^{2}: \eta^{2}$-peroxo intermediate from 1 and 4.

Table 3. Characteristic absorption of known $\mu-\eta^{2}: \eta^{2}$-peroxo species compared to $6 \& 7$.

\begin{tabular}{cccc}
\hline Oxidized Cu Center & $\begin{array}{c}\mathbf{1}_{\max } \mathbf{I} / \mathbf{n m} \\
\left(\mathbf{e} / \mathbf{M}^{-1} \mathbf{c m}^{-1}\right)\end{array}$ & $\begin{array}{c}\mathbf{1}_{\max } \mathbf{I I} / \mathbf{n m} \\
\left(\mathbf{e} / \mathbf{M}^{-1} \mathbf{c m}^{-1}\right)\end{array}$ & Reference \\
\hline $\mathbf{6}$ & $392(22000)$ & $581(820)$ & Guidote et al. 2001 \\
\hline $\mathbf{7}$ & $398(15000)$ & & This paper \\
\hline Oxyhemocyanin & $340(20000)$ & $580(1000)$ & Magnus et al. 1994 \\
\hline Oxytyrosinase & $345(18000)$ & $600(1200)$ & Kitajima et al. 1994 \\
\hline
\end{tabular}

The previous argument can be related to the $\mathrm{UV}$-vis spectra of the reaction of 4 and $\mathrm{H}_{2} \mathrm{O}_{2}$ at $-50^{\circ} \mathrm{C}$. At the start, there is the formation of the peroxo intermediate (Figure 8). After approximately two hours, still at $-50^{\circ} \mathrm{C}$, the spectrum changes into something totally different from the original complex. This is thought to be the decomposition of 4 .

The hydroxylation of a ligand's arene rings has been observed in synthetic systems using dinucleating ligands with meta-xylyl spacers, which due to their bridging position, are predisposed toward this intramolecular reaction. (Karlin et al. 1987) A substantial electronic effect on the rate of decomposition was observed with electron-withdrawing groups slowing down the rate of decomposition and electron-donating methoxy groups making the decomposition rate so fast that no intermediate could be observed. This bolsters the idea of 7 attacking 4 .

Bis m-oxo intermediates also are capable of hydroxylating arenes (Holland et al. 1999). The flexibility of the C-S-C angle of the ligands may be able to contract to such a low value to allow the formation of the bis m-oxo adduct (Guidote et al. 2001).

The occurrence of the attack was tested by the reduction of the concentration of 4 in the oxidation of external substrates. When 0.5 mol\% of 4 (in $\mathrm{CH}_{2} \mathrm{Cl}_{2}$ ) was used, the yield of the biphenol, based on the complex amount, went up to $4600 \%$. There were less chances of 7 attacking the other complexes 4 or 7 and increased chances of reacting with the more numerous phenol substrates. 
Low temperature and room temperature UVvis analysis of the oxidation of 2,4-dtbp was performed and for several hours, there was no change in the intensity of the peak at $444 \mathrm{~nm}$ and no peak at $398 \mathrm{~nm}$ is observed. There was an increase of the intensities of the peaks at 230-300 $\mathrm{nm}$ and this may indicate the formation of the biphenol. After some time, the $444 \mathrm{~nm}$ peak intensity slowly goes down. The time when there was no change in the $444 \mathrm{~nm}$ peak corresponds to the reaction of 7 with the substrate. When most of the substrate has reacted, 7 is able to react with other 4 or 7 resulting to the decrease in intensity of the $444 \mathrm{~nm}$ peak indicative of complex decomposition. TLC analysis of the reaction mixture shows a big spot at an $R_{f}$ where the coupling product is found.

With 4 as catalyst, the yield when 2,6-dtbp is used is lower since the reactivity of this substrate, compared to 2,4-dtbp, is lower. Intermediate 7 reacts more readily with other 4 resulting to the low yield. Complexes 1 and 2 as substrates are not as reactive as $\mathbf{4}$ and are able to react more with 2,6-dtbp (after the formation of the $\mu-\eta^{2}: \eta^{2}$ peroxo intermediate), thus the higher yield.

A mechanism is proposed to summarize and the oxidation reactions stated above.

In the mechanism, two paths are available and these are both accessible in as much as both intermediates $\mathbf{8}$ and $\mathbf{1 0}$ are possibly formed, both the coupling product and quinone are produced, and different amounts of products are obtained in $\mathrm{CH}_{2} \mathrm{Cl}_{2}$ and THF. In path $\mathrm{A}$, a $\mu-\eta^{2}: \eta^{2}$-peroxo intermediate, $\mathbf{8}$, is formed which reacts with two molecules of the phenol to produce the coupling products. If the biphenol is produced, this can be oxidized by $\mathbf{8}$ to the diphenoquinone. After $\mathbf{8}$ has abstracted a hydrogen atom, a $\mu$-hydroxo intermediate, 9, is formed which can once again react with $\mathrm{H}_{2} \mathrm{O}_{2}$ to form 8 for the oxidation path $\mathrm{C}$. Intermediate 9 can also react with $\mathrm{H}_{2} \mathrm{O}_{2}$ to form the $\mu$-hydroperoxo intermediate 10 with which the phenol radical is oxidized to quinone. Intermediate $\mathbf{1 0}$ can be accessed from the starting complexes through path B. The phenoxy radical can also be obtained by the reaction of phenol with the $\mathrm{OH}^{-}$radical coming from the $\mu$-hydroperoxo intermediate. After the reaction of $\mathbf{1 0}$ with the phenoxy radical, intermediate $\mathbf{1 1}$ is formed which can react with phenol to produce the phenoxy radical. At the same time, $\mathbf{1 1}$ is converted to 9 to complete another cycle.

\section{CONCLUSION}

In summary, the ligand bis[3-(2-hydroxy benzylideneamino) phenyl] sulfone and its derivatives were prepared and used for the syntheses of complexes $4-5$. These complexes have been found to be able to oxidize orthosubstituted phenols. Bulky alkyl groups in the 3 -position of the salicyl moiety of the ligand increase the catalytic activity of the complexes and enhance the yields of the oxidation products. The two complexes $\mathbf{4}$ and $\mathbf{5}$ were utilized in the oxidation of the substrates 2,4and 2,6-di-tert-butylphenol (dtbp) at $-50^{\circ} \mathrm{C}$ with $\mathrm{H}_{2} \mathrm{O}_{2}$ in $\mathrm{CH}_{2} \mathrm{Cl}_{2}$. For 2,4-dtbp, yields of $4,600 \%$ and $7,200 \%$ of 3,3',5,5'-tetra-tertbutyl-2,2'-biphenol were achieved with the use of $\mathbf{4}$ and 5, respectively. For 2,6-dtbp, yields of $1,900 \%$ and $400 \%$ of 3,3 ',5,5'-tetra-tert-butyl4,4'-biphenol were realized utilizing $\mathbf{4}$ and $\mathbf{5}$, respectively. Thus, these show that the methoxy groups activated the complex. Based on low temperature UV-vis results, a $\mu-\eta^{2}: \eta^{2}$ peroxo or a $\mathrm{m}$-hydroperoxo intermediate was possibly formed by the reaction of $\mathbf{4}$ with the $\mathrm{H}_{2} \mathrm{O}_{2}$. A mechanism was proposed to summarize these oxidation reactions mediated by complex 4 .

\section{ACKNOWLEDGEMENT}

We would like to thank the Japan Ministry of Education, Science, Sports and Culture (Monbusho) for financial support to AMG and we also thank Dr. Y. Inomata for her help in the measurements of magnetic moments. 


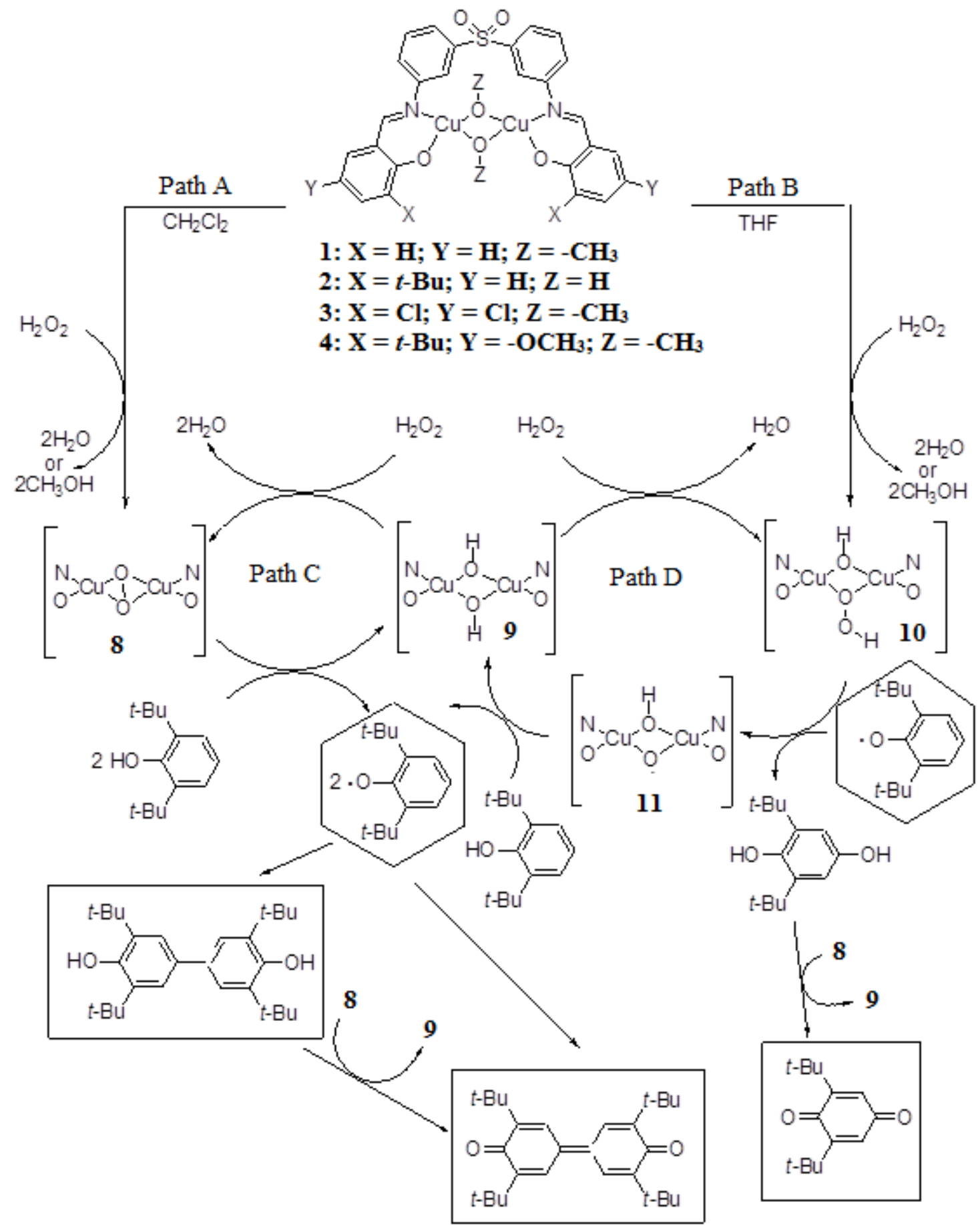

Figure 8. Plausible reaction mechanism for the oxidation of phenols using 1-4.

\section{REFERENCES}

Baron AJ, Stevens C, Wilmot C, Seneviratne $\mathrm{KD}$, Blakeley V, Dooley DM, et al. Structure and Mechanism of Galactose Oxidase. The Free Radical Site. J Biol Chem. 1994 Oct 7; 269(40):25095-25105.
Burton SG. Biocatalysis with polyphenoloxidase: a review. Catal Today. 1994; 22:459-87.

Cahoy J, Holland PL, Tolman WB. Experimental Studies of the Interconversion of Peroxo- and Bis(oxo)Dicopper Complexes. Inorg Chem. 1999; 38:2161-2168. 
Chiacchierini E, Restuccia D, Vinci G. Bioremediation of Food Industry Effluents: Recent Applications of Free and Immobilised Polyphenoloxidases. Food Sci Tech Int. 2004; 10(6):373-382.

Decker H, Tuczek F. Tyrosinase/ Catecholoxidase Activity of Hemocyanins: Structural Basis and Molecular Mechanism. Trends Biochem Sci. 2000; 25:392-397.

Duran N, Rosa MA, D’Annibale A, Gianfreda L. Application of laccases and tyrosinases (phenoloxidases) immobilised on different supports: a review. Enzyme Microb Technol. 2002; 31:907-31.

Estiu G. Recent Calculations in Proteins and Metalloenzymes In the frontiers of chemistry and biophysics [Internet]. [Place unknown]: [Publisher unknown]; 2004 Apr. Available from: http://www.qtp.ufl.edu/ kmmprogs/ links/archive/Guillermina-4-27-04.pdf.

Fenton D. Biocoordination Chemistry. New York: Oxford University Press; 1995.

Funabiki, T, editor. Oxygenases and Model Systems. Dordrecht: Kluwer Academic Publishers; 1997.

Funaki T, Takanohashi Y, Fukazawa H, Kuruma I. Estimation of kinetic parameters in the inactivation of an enzyme by a suicide substrate. Biochim Biophys Acta 1991; 1078:43-46.

Gamez P, Koval IA, Reedijk J. Bio-mimicking galactose oxidase and hemocyanin, two dioxygen-processing copper proteins. Dalton Trans. 2004 Dec 21; (24):4079-88.

Gerdemann C, Eicken C, Krebs B. The crystal structure of catechol oxidase: new insight into the function of type-3 copper proteins. Acc Chem Res. 2002; 35:183-191.

Guidote AM, Ando K, Kurusu Y, Nagao H, Masuyama Y. Synthesis and characterization of homodinuclear manganese and cobalt complexes bridged by a hemiacetal or by an acetate group in a $\mu-\left(\eta^{2}: \eta^{1}\right)$ bridging mode. Inorg Chim Acta. 2001; 314:27-36.

Guidote AM, Ando K, Terada K, Kurusu Y, Nagao H, Masuyama Y. Synthesis, characterization and reactivity of a series of dinuclear copper complexes bearing the ligand bis[3-(2-bydroxybenzylideneamino)phenyl] sulfone and derivatives. Inorg Chim Acta. 2001; 324:203-211.

Holland PL, Rodgers KR, Tolman WB. Is the Bis(Oxo)Dicopper Core Capable of Hydroxylating an Arene? Angew Chem Int Ed. 1999; 38:1139-1142.

Ikehata K, Nicell JA. Characterisation of tyrosinase for the treatment of aqueous phenols. Bioresour Technol. 2000; 74:191-9.

Karlin KD, Cruse RW, Gultneh Y. Dioxygencopper reactivity: a hydroperoxo-dicopper(II) complex. J Chem Soc Chem Commun. 1987; 599-600.

Karlin KD, Ghosh P, Cruse RW, Rarooq A, Gultneh Y, Jacobson RR, et al. Dioxygencopper reactivity: generation, characterization, and reactivity of a hydroperoxodicopper(II) complex. J Am Chem Soc. 1988; 110:67696780 .

Khenkin AM, Efremenko I, Weiner, L., Martin JML, Neumann R. Photochemical Reduction of Carbon Dioxide Catalyzed by a Ruthenium-Substituted Polyoxometalate. Chem Eur J. 2010; 16(4):1356-1364.

Kitajima N, Moro-oka Y. Copper-dioxygen Complexes. Inorganic and Bioorganic Perspectives. Chem Rev. 1994; 94:737-757.

Kleifeld O, Frenkel A, Martin JM, Sagi I. Active site electronic structure and dynamics during metalloenzyme catalysis. Nat Struct Biol. 2003 Feb; 10(2):98-103.

Lewis EA, Tolman WB. Reactivity of Dioxygen-Copper Systems. Chem. Rev. 2004; 104:1047-1076. 
Liang HC, Zhang CX, Henson MJ, Sommer RD, Hatwell KR, Kaderli S, et al. Contrasting Copper-Dioxygen Chemistry Arising from Alike Tridentate Alkyltriamine Copper (I) Complexes. J Am Chem Soc. 2002; 124:41704171.

Magnus KA, Ton-that $\mathrm{H}$, Carpenter JE. Recent Structural Work on the Oxygen Transport Protein Hemocyanin. Chem Rev. 1994; 94:727-735.

Mcmurry J, Simanek E. Fundamentals of Organic Chemistry. 6th Ed. California: Thomson Brooks/Cole; 2007. p. 242-243.

Mirica LM, Otttenwaelder X, Stack TDP. Structure and Spectroscopy of CopperDioxygen Complexes. Chem Rev. 2004; 104:1013-1045.

Mirica LM, Vance M, Rudd DJ, Hedman B, Hodgson KO, Solomon EI, et al. A Stabilized $\mu-\eta^{2}: \eta^{2}$-Peroxodicopper(II) Complex with a Secondary Diamine Ligand and Its Tyrosinase-like Reactivity. J Am Chem Soc. 2002; 124:9332-9333.

Ottenwaelder X, Rudd DJ, Corbett MC, Hodgson KO, Hedman B, Stack TDP. Reversible O-O Bond Cleavage in CopperDioxygen Isomers: Impact of Anion Basicity. J Am Chem Soc. 2006; 128:9268-9269.

Panek JJ, Ward TR, Jezierska-Mazzarello A, Novič. Flexibility of a biotinylated ligand in artificial metalloenzymes based on streptavidin-an insight from molecular dynamics simulations with classical and $a b$ initio force fields. J Comput Aided Mol Des. 2010 Sep; 24(9):719-732.

Punniyamurthy T, Velusamy S, Iqbal J. Recent Advances in Transition Metal Catalyzed Oxidation of Organic Substrates with
Molecular Oxygen. Chem Rev. 2005; 105(6):2329-2364.

Robb DA. Tyrosinase. In: Lontie R, editor. Copper proteins and copper enzyme, Vol. II. Boca Raton, FL: CRC Press; 1984. p. 208-40.

Rompel A, Fischer $\mathrm{H}$, Meiwes $\mathrm{D}$, Büldtkarentzopoulos K, Dillinger R, Tuczek F, et al. Purification and spectroscopic studies on catechol oygenases from Lycopus europaeus and Populus nigra: evidence for a dinuclear center of type 3 and spectroscopic similarities to tyrosinase and hemocyanin. J Biol Inorg Chem. 1999; 4:56-63.

Simándi LI, editor. Advances in Catalytic Activation of Dioxygen by Metal Complexes. London: Kluwer Academic Publishers; 2003.

Solomon EI, Chen P, Metz M, Lee SK, Palmer AE. Oxygen Binding, Activation, and Reduction to Water by Copper Proteins. Angew Chem Int Ed. 2001; 40:4570-4590.

Solomon EI, Sundaram UM, Manchokin TE. Multicopper oxidases and oxygenases. Chem Rev. 1996; 96:2563-2606.

Tolman WB. Using synthetic chemistry to understand copper protein active sites: a personal perspective. J Biol Inorg Chem. 2006 Apr;11(3):261-71.

Wang RX, You XZ, Meng QJ, Mintz EA, Bu XR. A Modified Synthesis of o-Hydroxyaryl Aldehydes. Synth Commun. 1994; 24:17571760 .

Wang YD, Dubois JL, Hedman B, Hodgson KO, Stack TDP. Catalytic galactose oxidase models: Biomimetic $\mathrm{Cu}(\mathrm{II})$-phenoxyl-radical reactivity. Science. 1998; 279:537-540. 